\title{
HOW HABITAT DEGRADATION THROUGH FISHERY DISTURBANCE ENHANCES IMPACTS OF HYPOXIA ON OYSTER REEFS
}

\author{
Hunter S. Lenihan ${ }^{1}$ And Charles H. Peterson \\ University of North Carolina at Chapel Hill, Institute of Marine Sciences, Morehead City, \\ North Carolina 28557, USA
}

\begin{abstract}
Oysters are ecosystem engineers that create biogenic reef habitat important to estuarine biodiversity, benthic-pelagic coupling, and fishery production. Prevailing explanations for the dramatic decline of eastern oysters (Crassostrea virginica) during the last century overlook ecosystem complexity by ignoring interactions among multiple environmental disturbances. To explain oyster loss, we tested whether (1) mortality of oysters on natural oyster reefs varies with water depth $(3 \mathrm{~m}$ vs. $6 \mathrm{~m})$, (2) harvesting by oyster dredges reduces the height of oyster reefs, and (3) bottom-water hypoxia/anoxia and reduction in reef height through fishery disturbance interact to enhance mortality of oysters in the Neuse River estuary, North Carolina, USA. The percentage of oysters found dead (mean $\pm 1 \mathrm{SD}$ ) during a survey of natural reefs in May 1993 was significantly greater at $6-\mathrm{m}(92 \pm 10 \%)$ than at $3-\mathrm{m}(28 \pm 9 \%)$ water depth. Less than one season's worth of oyster dredging reduced the height of restored oyster reefs by $\sim 30 \%$. During stratification of the water column in summer, oxygen depletion near the seafloor at $6 \mathrm{~m}$ caused mass mortality of oysters, other invertebrates, and fishes on short, deep experimental reefs, while oysters and other reef associates elevated into the surface layer by sufficient reef height or by location in shallow water survived. Highly mobile blue crabs (Callinectes sapidus) abandoned burrows located in hypoxic/anoxic bottom waters but remained alive in shallow water. Our results indicate that interaction of reef habitat degradation (height reduction) through fishery disturbance and extended bottom-water hypoxia/anoxia caused the pattern of oyster mortality observed on natural reefs and influences the abundance and distribution of fish and invertebrate species that utilize this temperate reef habitat. Interactions among environmental disturbances imply a need for the integrative approaches of ecosystem management to restore and sustain estuarine habitat.
\end{abstract}

Key words: biogenic reef habitat; Crassostrea virginica, decline of; ecosystem management; estuarine ecosystems; field experiment; habitat degradation through fishery disturbance; habitat structure; hypoxia effects; Neuse River estuary, North Carolina, USA; oyster reefs, reduced reef height of; water depth.

\section{INTRODUCTION}

The physical structure of biogenic habitat, including its architectural complexity, location in space, and size, profoundly influences its ecological function (Bell et al. 1991). For example, species richness within a habitat often increases with architectural complexity (e.g., MacArthur and MacArthur 1961, Murdoch et al. 1972, Leather 1986), in part because complexity allows for the coexistence of competitors (e.g., Klopfer and MacArthur 1960, MacArthur and Levins 1964) and provides refuges for prey from their predators (e.g., Gause 1934, Holt 1984, Hixon and Menge 1991). Other physical characteristics of habitat, such as location along an environmental gradient and size, can influence the abundance and distribution of species by providing refuge from environmental stress. For example, tall trees

Manuscript received 14 April 1997; accepted 7 May 1997; final version received 25 June 1997.

${ }^{1}$ Present address: NOAA-National Marine Fisheries Service, Beaufort Laboratory, 101 Pivers Island Rd., Beaufort, North Carolina 28516 USA. on mountain sides capture and precipitate fog, thereby providing refuge from desiccation for understory flora (Wilson and Agnew 1992). Organisms that create biogenic habitat with their own physical structure and control resources used by other species (e.g., availability of refuges) have been called "ecosystem engineers" (Jones et al. 1994).

The marine environment contains several ecosystem engineers that create biogenic habitat whose physical structure is important in regulating local population and community dynamics (Bell et al. 1991, Jones et al. 1994). For example, topography, morphology, and structural heterogeneity often control recruitment, persistence, and diversity of species inhabiting coral reefs (Genin et al. 1986, Hixon and Beets 1993), seagrass patches (Heck and Orth 1980, Irlandi and Peterson 1988, Irlandi 1996), salt marshes (Kneib 1984), and kelp beds (e.g., Simenstad et al. 1978, Tegner and Dayton 1987, Estes and Duggins 1995). Recent experimental evidence indicates that physical disturbances caused by marine fishing can alter the physical structure of marine biogenic habitat and negatively affect pop- 
ulations and communities of economically valuable species (e.g., Peterson et al. 1987, Hatcher et al. 1989, Russ and Acala 1989, Northridge 1991, Dayton et al. 1995). Such evidence has led to regulatory protection of coral reefs, kelp forests, seagrasses, and salt marshes from many direct anthropogenic disturbances in many countries worldwide. Similar regulatory efforts to preserve marine biogenic reefs in temperate zones, like those created by polychaetes (Wilson 1979, Reise 1982), vermetid gastropods (Safriel 1975), and oysters (Bahr and Lanier 1981, Zimmerman et al. 1989), have not been made, largely because temperate reefs either are not considered valuable habitat (polychaetes and gastropods) or are heavily exploited in a fishery (oysters). At present, we do not adequately recognize the suite of ways in which the physical structure (e.g., height) of biogenic habitat interacts with the physical/ chemical environment to influence a habitat's function (but see Belsky et al. 1989, Breitburg et al. 1995, Leichter and Witman 1997).

Oysters are ecosystem engineers that create biogenic reef habitat in the intertidal and subtidal marine environment worldwide (e.g., Purchon 1977). Eastern oysters (Crassostrea virginica Gmelin) can create large reefs in estuaries of eastern North America that are habitat to many species of fishes (Arve 1960, Breitburg 1992), invertebrates (Wells 1961, Dame 1979, Bahr and Lanier 1981), and algae (Wells 1961, Bahr and Lanier 1981). Oyster reefs are important to the maintenance of biological diversity in estuaries because they provide emergent hard substrate on otherwise flat soft-sediment bottoms (Wells 1961). Oyster reefs form in estuaries when planktonic oyster larvae settle onto oyster shells to which they are attracted by biochemical cues (Turner et al. 1994). Oyster reefs in the subtidal environment can reach several hectares in area and $4 \mathrm{~m}$ in height (e.g., Ingersoll 1881, Winslow 1889, DeAlteris 1988). One important ecosystem function of oyster reefs is the provision of refuge for reef-associated invertebrates and fishes from environmental stress, including desiccation (Wells 1961) and heavy sediment deposition (Grant et al. 1990). Two studies in Chesapeake Bay (Seliger et al. 1985, Breitburg 1992) found that oyster reefs located in shallow water provided refuge for oysters and other reef-associated organisms from hypoxia that occurred in deep water.

Dissolved-oxygen concentration is a critical component of water quality affecting survival of oysters and other sessile benthic invertebrates and sedentary fishes (Seliger et al. 1985, Jordan et al. 1992). Mesohaline regions of estuaries can experience occasional periods of low oxygen in bottom waters when the water column stratifies for a sufficiently long time (e.g., Tenore 1972, Officer et al. 1984, Turner et al. 1987, Smith et al. 1992, Stanley and Nixon 1992). Stratification is induced by stormwater or river runoff and solar heating, which reduce surface water density, and by low wind stress, insufficient to mix the water column. Un- der stratification, oxygen consumed during microbial decomposition of organic materials settling to bottom water or the estuarine floor is not replaced by mixing with well-oxygenated surface waters. Microbial decomposition is intensified during summer, when temperatures are higher and when availability of labile carbon has been enhanced by recent deposition of algae from plankton blooms. If stratification persists long

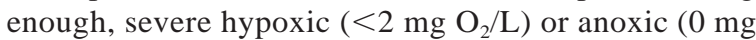
$\mathrm{O}_{2} / \mathrm{L}$ ) conditions develop in bottom waters due to microbial respiration, resulting in stress and mass mortality of resident organisms (e.g., Tenore 1972, Seliger et al. 1985, Llanso 1993). A growing number of studies indicate that increasing eutrophication of rivers and estuaries from greater fertilizer use, discharge of animal and human wastes, conversion and destruction of riparian wetlands, and increased atmospheric nitrogen deposition has probably intensified low-oxygen stress in many estuaries (Paerl 1985, Cooper and Brush 1991, Smith et al. 1992, Dyer and Orth 1994, Nixon 1995), potentially increasing the duration, frequency, and spatial scale of oxygen-depletion events.

The eastern oyster is a heavily exploited species supporting a multi-million dollar fishery in North America (MacKenzie 1996). Over the past century, fishery landings of eastern oysters have declined by $>90 \%$ in most of the estuaries of Atlantic coastal states (MacKenzie 1996), including Delaware Bay (Ford 1996), Chesapeake Bay (Hargis and Haven 1988), and Pamlico Sound, North Carolina (Frankenberg 1995). Over 50\% of the area of oyster reef habitat has disappeared from Chesapeake Bay (Rothschild et al. 1994), and similar declines in habitat have been reported from other east coast and Gulf Coast states (MacKenzie 1996). Mechanical harvesting of oysters using dredges and hydraulic-powered tongs extracts both living oysters and the attached shell matrix and has been blamed for a significant proportion of the removal and degradation of oyster reef habitat (Reise 1982, Hargis and Haven 1988, Northridge 1991, Rothschild et al. 1994, Dayton et al. 1995). Several studies report that mechanical oyster harvesting in Chesapeake Bay has reduced the height of oyster reefs by up to several meters over the last century (Marshall 1954, DeAlteris 1988). Other explanations for the dramatic decline in oysters and oyster reef habitat have been advanced, including overfishing of oyster broodstock (Gross and Smyth 1946, Hargis and Haven 1988, Rothschild et al. 1994), deterioration in water quality (Seliger et al. 1985, Thain and Waldock 1986), and the introduction and spread of disease (Ford and Tripp 1996). Aside from studies concerning disease (e.g., Fisher 1996), analysis of oyster and oyster-reef loss has not employed experimental hypothesis testing and has failed to explore interactions between factors.

When multiple environmental disturbances each affect a population or community, then assessing their joint impact requires knowledge of whether the dis- 


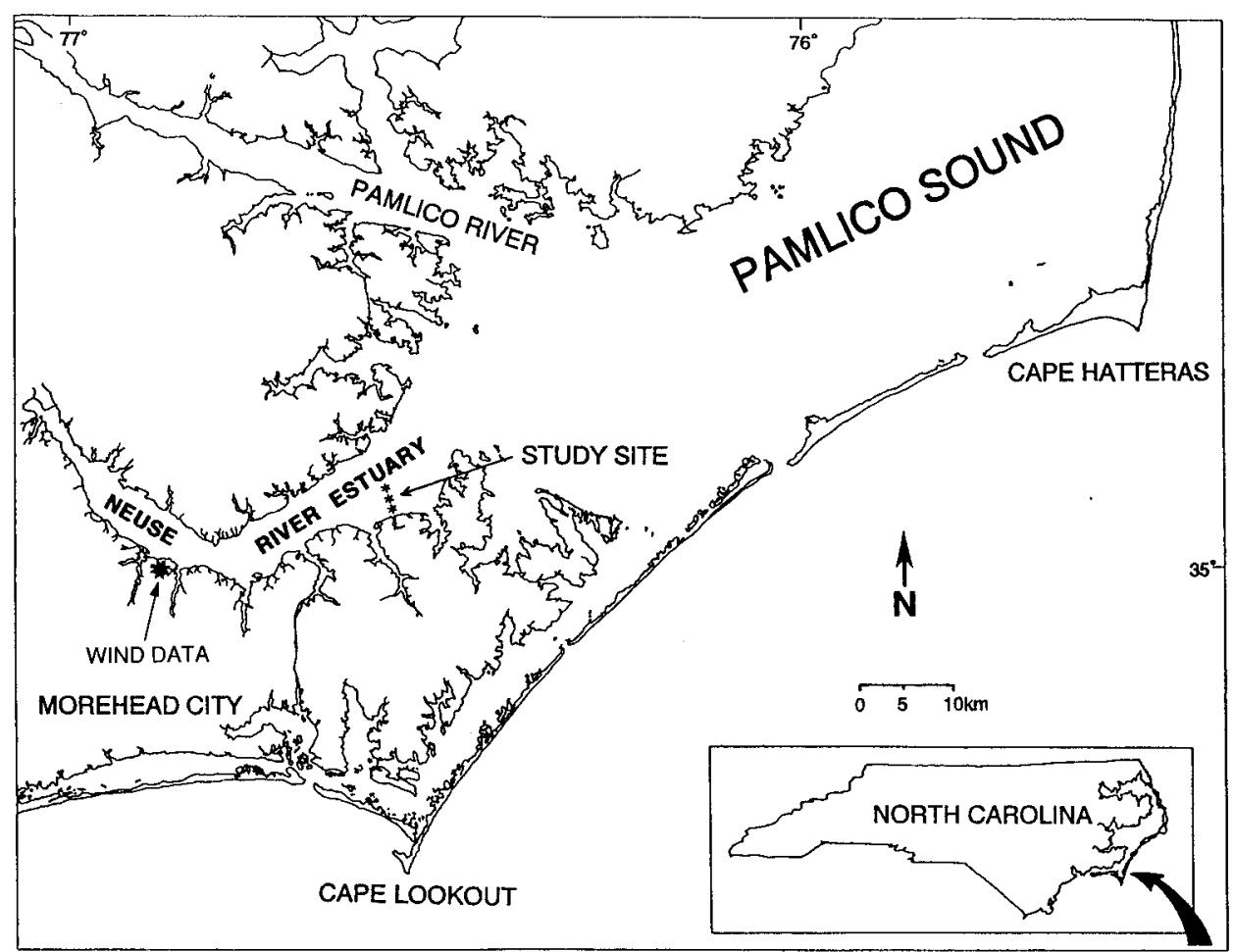

FIG. 1. Study site in the Neuse River estuary, North Carolina, USA. The location of experimentally restored oyster reefs is indicated by asterisks $\left(^{*}\right)$, with each asterisk representing a set of restored reefs at either 3-, 4-, or 6-m water depth (6-m reefs are farthest, and 3-m reefs are closest, to the southern shore). The location where wind speed measurements were recorded is indicated by a blackstar.

turbances act independently. In the absence of independence, interaction among factors implies that the effects of one factor are contingent on the levels of others. For example, Peterson and Black (1988) showed that sedimentation and history of crowding in two species of clams interacted, in such a way that the rate of mortality caused by sedimentation was contingent on the degree of crowding during the clam's recent history. Oyster populations also appear to be influenced by interaction among environmental factors. Chu et al. (1994) found that interaction between elevated water salinity and temperature increased the intensity of parasitic infection in oysters and helped explain the spatial patterns of oyster mortalities in Chesapeake Bay.

In this paper we test the hypothesis that oyster loss in the Neuse River estuary, North Carolina, results from the interaction of bottom-water hypoxia and the effect of fishery disturbance on habitat structure. To test this hypothesis, we (1) sampled natural oysters reefs in deep $(6 \mathrm{~m})$ and shallow $(3 \mathrm{~m})$ water to determine patterns of oyster mortality, (2) performed a field experiment to determine the effect of harvesting by oyster dredges on the height of oyster reefs, and (3) conducted a field experiment in which we restored oyster reefs using a factorial design that varied reef height, as a proxy for effects of oyster dredging on physical habitat structure, and water depth, as a means of manipulating exposure to seasonal hypoxia/anoxia that occurs below the mixed zone during summer stratification. We also sampled the abundance and distribution of blue crabs (Callinectes sapidus Rathbun) before and during hypoxic conditions, and observed the distribution and condition of reef fish and invertebrates during hypoxic conditions, to determine the effect of hypoxia on important reefassociated organisms.

\section{Methods \\ Study site}

The Neuse River estuary, North Carolina, USA (Fig. 1) represents typical mesohaline habitat where eastern oysters form subtidal reefs. Natural oyster reefs are found primarily in water depths $>5 \mathrm{~m}$ in the Neuse, but a small proportion of reefs $(\sim 20 \%)$ is found in $3-$ $4 \mathrm{~m}$ of water (North Carolina Division of Marine Fisheries [NCDMF; Morehead City, North Carolina, USA], unpublished data; H. S. Lenihan, personal observation). Traditional knowledge (i.e., Johannes 1976) of 10 local fishermen indicates that the estuary supported a productive oyster fishery prior to the $1950 \mathrm{~s}$ and that the harvest of oysters from natural reefs in the Neuse has declined dramatically over the last $45 \mathrm{yr}$. Over the last decade, oyster harvests have come predominantly from restored oyster reefs that are located in water depths $<5 \mathrm{~m}$ (NCDMF, unpublished data). We also know that over the last century the height of nat- 
ural oyster reefs located in deep portions $(>5 \mathrm{~m})$ of the estuary, where oyster dredging once occurred, has declined. In June 1993 we conducted a bathymetric survey of natural oyster reefs in the Neuse for contrast with a bathymetric survey conducted by the U.S. Coast and Geodetic Survey (USCGS) in 1868 (USCGS 1868). We found that topographic high points $(n=6)$ in the river in 1868 , that were approximately $1.8-2.4 \mathrm{~m}$ tall, are oyster reefs now only $0.3-0.9 \mathrm{~m}$ tall. There were no reefs taller than $1.2 \mathrm{~m}$ in our 1993 survey. It is probable that reduction in reef heights in the Neuse River estuary is due to decades of fishery-related disturbances caused by oyster dredging, as is the case in Chesapeake Bay (e.g., DeAlteris 1988, Rothschild et al. 1994). Since deeper portions of estuaries are subject to bottom-water hypoxia (e.g., Paerl et al. 1995), it is also likely that the tops of tall, undisturbed oyster reefs located in deep water once provided a spatial refuge for oysters and reef-associated organisms from stressful hypoxic conditions.

\section{Sampling of oysters on natural oyster reefs}

To determine if the proportion of oysters found dead on natural oyster reefs located in the Neuse River estuary differs with water depth, we sampled the number of live vs. dead oysters on natural reefs found in 3-m and 6-m water depths. We counted oysters with shell heights $\geq 10 \mathrm{~mm}$ only. We assumed that this is a crude measure that integrates mortality over the recent past, months or years. In May 1993, divers sampled oysters with $200.10-\mathrm{m}^{2}$ quadrats randomly placed on the crests of six replicate reefs located at each water depth. All reefs sampled were $0.6-0.9 \mathrm{~cm}$ tall. Reefs sampled at 6-m water depth were within the same region of the estuary where USCGS (1868) reported reefs a century earlier as being $>1.8 \mathrm{~m}$ tall.

\section{Effect of fishery disturbance on reef height}

We tested the hypothesis that disturbance caused by oyster harvesting using dredges reduces the height of oyster reefs by constructing eight experimental oystershell reefs ( $1 \mathrm{~m}$ tall, $16-20 \mathrm{~m}^{2}$ in area) in $3-\mathrm{m}$ water depth in the Neuse River estuary. Reefs were built in July 1993 with help from the NCDMF using methods employed in their oyster reef restoration program. Replicate reefs were constructed by dumping oyster shell from a remodeled 35-m U.S. Navy LCU-1466 landing craft using a bulldozer. The height of each reef was measured during construction by divers using a plumb line attached to a buoy: shell was added or removed accordingly. By February 1995, the reefs supported a high density (420-610 individuals $/ \mathrm{m}^{2}$ ) of oysters resulting from two heavy colonizations of oyster larvae that occurred during August-October of 1993 and 1994 (H. S. Lenihan, unpublished data).

In February 1995 we subjected four of the eight replicate reefs to oyster dredging, while four reefs were left unharvested as controls. A professional oyster-fish- ing boat and crew dredged experimental reefs until the catch of market-sized $(7.5 \mathrm{~cm}$ in height) oysters in each haul had declined to near zero and remained constant, in order to simulate realistic harvest effort equal to approximately the minimum seasonal effort. Maximum harvest effort for a season would likely include additional harvest disturbances caused by oyster fishers when sampling reefs to approximate their potential yield. The height of harvested and unharvested reefs was measured $3 \mathrm{~d}$ before and again $2 \mathrm{~d}$ after the harvest treatment was applied.

\section{Experimental reef restoration}

We tested the hypothesis that the interaction between reef height and water depth causes loss of oysters experimentally by constructing 12 replicate restored oyster-shell reefs of two heights (1 m [short, "dredged"] and $2 \mathrm{~m}$ [tall, "natural-sized"]) at each of two water depths (3 and $6 \mathrm{~m}$ ) in the Neuse River estuary, with an additional set of 12 short reefs at 4-m water depth (for a total of 60 reefs, Fig. 2). Short reefs were 16$20 \mathrm{~m}^{2}$ in area and tall reefs were $33-38 \mathrm{~m}^{2}$ in area. The distance between reefs was $18-32 \mathrm{~m}$. Reefs were built in the same manner as for the fishery disturbance experiment (see above). For a year, beginning in August 1993, we monitored temperature, salinity, and dissolved-oxygen concentration around the reefs as a function of water depth and elevation off bottom. We also followed oyster colonization and fate as a function of water depth, reef size, and position on reefs (base vs. crest).

\section{Hydrographic and wind measurements}

Water temperature, salinity, and dissolved-oxygen concentration (DO) were measured from September 1993 until August 1994 at the 3-, 4-, and 6-m stations around experimental reef sites using three methods. Vertical temperature profiles were collected during five $>30$-d periods with a string of HoboTemp temperature loggers (Onat Computer, Pocasset, Massachusetts, USA) sampling every $24 \mathrm{~min}$ at 1.5 -m or finer depth intervals. Salinity and DO were measured at $5.5 \mathrm{~m}$ at the base of a tall reef at the 6-m station every $24 \mathrm{~min}$ also during five $>30$-d periods using a moored SeaCat 16-DO CTD (Sea Bird, Seattle, Washington, USA [CTD = conductivity-temperature-depth monitor]). A profiling H-20 CTD (Hydrolab, Austin, Texas, USA) was deployed occasionally from a boat to provide additional salinity and DO measurements at selected depths at the 3- and 4-m stations. All water quality monitoring equipment was calibrated in the laboratory before and after deployment in order to correct for any drift in measurements. We obtained wind data from the U.S. National Weather Service, which records wind speed and direction hourly along the Neuse River estuary at a location $16 \mathrm{~km}$ upstream (see Fig. 1) from our experimental reefs. 


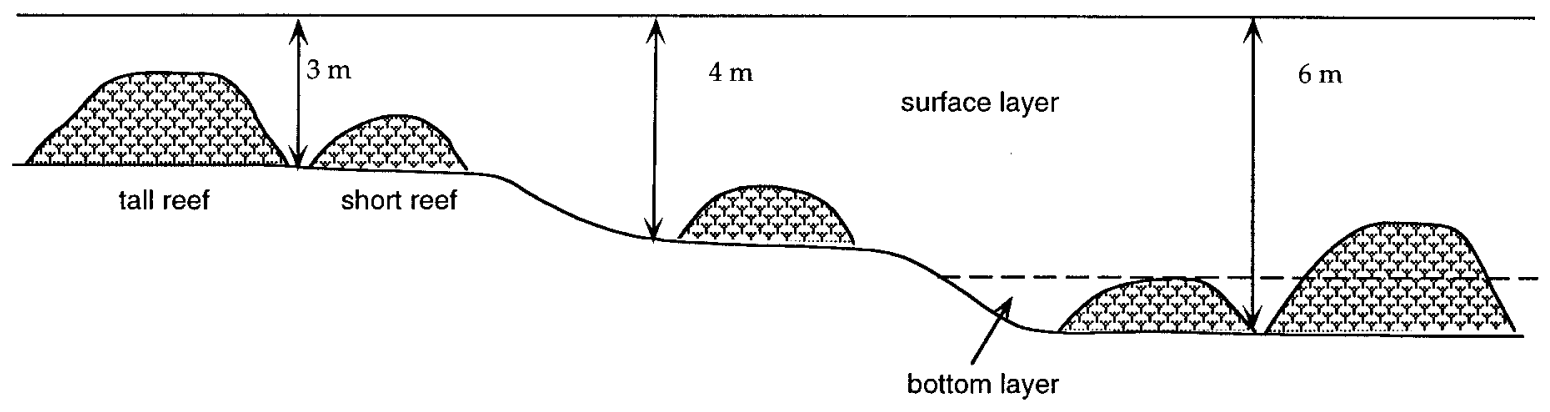

$1.5 \mathrm{~km}$

FIG. 2. Experimentally restored oyster reefs in the Neuse River estuary, North Carolina. Sets of tall reefs (2-m in height, $n=12)$ and short reefs (1-m in height, $n=12)$ were located at both $3-\mathrm{m}$ and $6-\mathrm{m}$ water depths, and short reefs $(n=12)$ were located at 4-m water depth. In this schematic diagram the horizontal scale of river width is grossly compressed, and slightly decreased for experimental reefs. Actual diameter of tall reefs was 6.5-7.5 m, and diameter of short reefs was 4.5$5.5 \mathrm{~m}$. Actual distance between reefs was $18-32 \mathrm{~m}$.

\section{Sampling of oysters on experimental reefs}

The fate of oysters on experimental reefs was determined using three separate sampling techniques, which were designed for different purposes. The three sets of data are presented together in this study to provide before-vs.-after contrasts of the effects of hypoxia on oyster reef communities. As a means of quantifying oyster recruitment, oyster colonization mats were placed on reefs in August 1993. Mats were sampled on 21 May 1994, and provide a measure of differences in oyster mortality among reef treatments within the period August 1993-May 1994. To measure the survival and growth of oysters on experimental reefs, juvenile hatchery-raised oysters were placed in cages on reefs in August 1993. Cages were sampled on 5 July 1994 to provide another before-hypoxia comparison of oyster mortality among treatments. Finally, the density and status (live vs. dead) of oysters located on experimental reefs after hypoxia was determined from quadrat counts. The various data sets were used to infer oyster mortality caused by two extended hypoxic/anoxic events that occurred during July-August 1994.

Recruitment mats were placed on reefs to function as repeatable sampling units for assessing oyster recruitment. Mats were $0.16-\mathrm{m}^{2}$ squares of $1.3-\mathrm{cm}$ polyethylene plastic mesh upon which 10 oyster shells (60$70 \mathrm{~mm}$ in height) were attached using plastic cable ties. Half the reefs (six) in each depth $\times$ height combination received mats at bases and half at crests. To test whether recruitment mats provided representative estimates of oyster density on reefs, we sampled in June 199410 mats from bases of 6-m reefs and compared their oyster densities to those within $100.16-\mathrm{m}^{2}$ quadrats haphazardly placed on the bases of other 6-m reefs. Oyster densities (mean $\pm 1 \mathrm{SD})$ on mats $(158 \pm 39$ oysters) and in quadrats $(141 \pm 30$ oysters) were indistinguishable $(t$ test; $t=1.08$; df $=18 ; P=0.30)$.

Cages containing oysters were placed on reefs to determine survival of genetically similar, hatcheryraised oysters. Cages $(30 \mathrm{~cm}$ long $\times 30 \mathrm{~cm}$ wide $\times 20$ $\mathrm{cm}$ tall) prevented predation by large crabs and fishes (H. S. Lenihan, unpublished data). Cages were made of $1.3-\mathrm{cm}$ polyethylene plastic mesh and were attached to steel rebar frames. On 10 August 1993, four replicate cages were staked to the base of each of six randomly selected tall reefs and six short reefs located at both 3$m$ and 6- $m$ water depths. An additional set of four cages was staked to the crest of each of the six remaining tall and short reefs at each depth. Each cage contained 10 juvenile oysters (20-25 $\mathrm{mm}$ in height) that had been colored with Alizarin red dye in order to distinguish them from any subsequent recruits.

On 2 August 1994, six quadrat $\left(0.10 \mathrm{~m}^{2}\right)$ collections were made by divers at various elevations (given below) on six replicate tall and four short reefs at both $3-\mathrm{m}$ and 6-m water depths, and on six short reefs located at 4-m depth. The six quadrat samples were collected at haphazardly selected distances along 10-m transect lines placed along three elevation contours on short reefs (near the base, $40 \mathrm{~cm}$ above the base, and the crest) and along five elevation contours on tall reefs (the base, $40 \mathrm{~cm}, 90 \mathrm{~cm}$, and $120 \mathrm{~cm}$ above the base, and the crest). To prevent biased sampling, quadrats were placed haphazardly along transect lines by swimming in the turbid water $(\sim 1 \mathrm{~m}$ visibility), far enough above the reef $(1 \mathrm{~m})$ so that only the white-colored transect tape and no oysters were visible, and dropping the quadrats onto the transect tape. All shell substratum together with oysters within quadrats was collected to a depth of $20 \mathrm{~cm}$. Recruitment mats and shell material from quadrat collections made in June 1994 (those used in the comparison of oyster density on mats vs. reef substrate) were returned to the laboratory where the status (live vs. dead) of oysters with shell heights of $\geq 10 \mathrm{~mm}$ was determined. For quadrat samples taken in August, the status of oysters with shell heights of 
$\geq 20 \mathrm{~mm}$ was determined. These minimum sizes for oysters were chosen to avoid quantifying the condition of small new recruits not part of the initial introduction. Hatchery-raised oysters placed in cages were distinguishable from new recruits because the hatcheryraised oysters were large and retained some of the red dye color.

\section{Observations of invertebrates and fishes}

To describe how hydrographic conditions influence the utilization of oyster reefs by motile invertebrate and sedentary fish inhabitants, we (1) sampled blue crab (Callinectes sapidus Rathbun) occupancy of reefs and (2) observed the distribution and status (live vs. dead) of small, sedentary reef inhabitants. On 3 June 1994 divers identified and marked occupied burrows of blue crabs on the bases of four small reefs at each of 3-, 4-, and 6-m water depths. Each reef sampled contained one or two burrows $(n=4$ at $3 \mathrm{~m}, n=5$ at $4 \mathrm{~m}$, and $n=5$ at $6 \mathrm{~m}$ ). Burrows were identified as being occupied or unoccupied by visually inspecting their entire volume. Continued (i.e., 100\%) occupation was verified by reexamination after 2 wk. On 3 August 1994, following the anoxia events, burrow occupation by $C$. sapidus was again assessed as a function of water depth. On 2 August 1994 divers swam across all experimental reefs located at 3-, 4-, and 6-m water depths and recorded the position and status (live vs. dead) of visible mud crabs (Panopeus herbstii Milne Edwards, Eurypanopeus depressus Smith) and benthic fishes (Chasmodes bosquinas Lacépéde, Hyposoblennius hentzi Lesueur). The status of animals was ascertained by physically manipulating them on reefs for signs of life when condition was not obvious and collecting several specimens for examination on the surface aboard the support boat.

\section{Statistical analyses}

We used one-tailed $t$ tests to determine if there was a statistically significant difference (1) in oyster mortality between natural oyster reefs located at 3-m and 6-m water depths in the Neuse River and (2) in the heights of dredged and unharvested reefs in our harvest disturbance experiment. The change in reef height (i.e., height before treatment minus height after treatment) was the response variable compared in the $t$ test for the harvest disturbance experiment. We used analysis of variance (ANOVA) to test whether mean proportion of dead oysters collected on recruitment mats, in cages, and within quadrats differed among treatments on experimental oyster reefs. We were able to maintain statistically independent measurements of the effect of position on reef by using only one position (crest or base) per replicate reef. Two separate ANOVAs were conducted on mean proportion of dead oysters from recruitment mats: (1) a three-factor ANOVA using reefs from 3- and 6-m water depths, in which water depth (3 m vs. $6 \mathrm{~m})$, reef height (tall vs. short), and position on reef were all crossed, fixed factors; and (2) a two-factor ANOVA using only short reefs, in which water depth $(3,4$, and $6 \mathrm{~m})$ and position were crossed, fixed factors. A three-factor ANOVA was conducted on mean proportion dead in cages using water depth ( $3 \mathrm{~m}$ vs. $6 \mathrm{~m}$ ), reef height (tall vs. short), and position on reef as crossed, fixed factors. Our sampling of oyster mortalities using quadrat counts on 2 August 1994 lacked statistical independence regarding the effect of position on reef because we collected data from each elevation on every reef sampled. In order to compare these data, we conducted a Monte Carlo procedure with replacement, in which we randomly assigned subsets of data from the bases or crests of separate reefs of each height (three for each position $\times$ height combination) from the 3 - and $6-\mathrm{m}$ sites into 20 combinations for analysis in 20 separate three-factor ANOVAs. The three factors in the ANOVAs-water depth (3 m vs. 6 $\mathrm{m})$, reef height (tall vs. short), and position on reef (base vs. crest only)-were crossed and fixed. Homogeneity of variance was tested before ANOVAs using Cochran's test. Post-hoc multiple comparisons tests were performed on mean proportion dead using Student-Newman-Keuls (SNK) methods. Finally, we tested whether the pattern of burrow occupancy by blue crabs varied with water depth after hypoxia using a $\chi^{2}$ test of a $2 \times 3$ contingency table (two burrow conditions [occupied vs. unoccupied] by three water depths). The $\chi^{2}$ test was effectively a before-vs.-after hypoxia comparison because burrows were $100 \%$ occupied before hypoxia and data used in the test were numbers of burrows that (1) remained occupied or (2) were abandoned across time spanning the period before to after hypoxia.

\section{RESUlts}

\section{Mortality of oysters on natural oyster reefs}

The proportion of oysters found dead on natural oyster reefs in the Neuse River estuary differed dramatically with water depth. Quadrat sampling in May 1993 showed that there was a significantly greater mean $( \pm 1$ SD) percentage of dead oysters at 6-m $(92 \pm 10 \%)$ than at $3-\mathrm{m}(28 \pm 9 \%)$ water depth $(t=13.53 ; \mathrm{df}=10, P$ $<0.0001)$.

\section{Effect of fishery disturbance on reef height}

Oyster dredging reduced the mean ( \pm 1 SD) height of $1 \mathrm{~m}$ tall restored oyster reefs by $29 \pm 6 \mathrm{~cm}$. In contrast, unharvested (i.e., control) reefs lost $1 \pm 1 \mathrm{~cm}$ of height over the 1-wk duration of the experiment. After application of our harvest treatment, which was equivalent to the disturbance of less than a single harvest season, harvested reefs had lost significantly more height than control reefs ( $t$ test; $t=4.77$, df $=6, P=$ $0.001)$. The greatest single loss in height of a harvested reef was $41 \mathrm{~cm}$ (41\% of total reef height). 


\section{Hydrographic measurements}

Hydrographic measurements revealed only two periods of thermal stratification and bottom-water hypoxia from September 1993 through April 1994, neither lasting longer than $3 \mathrm{~d}$. During a 5 -d period in May 1994, dissolved oxygen (DO) dropped from 6 to $1 \mathrm{mg} / \mathrm{L}$ near the seafloor at $6 \mathrm{~m}$ but increased back to $>6 \mathrm{mg} / \mathrm{L}$ on the sixth day after intense southwest winds of 11-14 m/s. From 21 June until 2 August 1994 at least two stratification events occurred at the 6-m station, each lasting $>5 \mathrm{~d}$ (Fig. 3). The longest record of thermal stratification lasted from 8 until after 19 July, during a period when normally strong and persistent southwest winds along the axis of the estuary switched to the south and remained at speeds $<5.5 \mathrm{~m} / \mathrm{s}$. Salinity and temperature records indicate strong stratification during this period, while bottom-water DO at the 6-m location revealed persistence of severe hypoxia and anoxia. This hypoxia/anoxia lasted from 8 to 23 July and reappeared from 28 July until 2 August. Temperature profiles taken at the 3-m and 4-m stations never exhibited thermal stratification, and bottom-water DO was never observed below $3.9 \mathrm{mg} / \mathrm{L}$ (Fig. 3).

\section{Oyster mortality on recruitment mats prior to hypoxic events}

Larval oysters settled heavily on restored reefs in late August-early September 1993 and grew to a shell height (mean $\pm 1 \mathrm{sD})$ of $39 \pm 11 \mathrm{~mm}(n=6000)$ by May 1994. Densities (mean $\pm 1 \mathrm{SD}, n=120$ ) of oysters on recruitment mats sampled on 21 May 1994 varied from $106 \pm 41$ (at $3 \mathrm{~m}$ ) to $58 \pm 23$ (at $4 \mathrm{~m}$ ) to $146 \pm$ 38 individuals (at $6 \mathrm{~m}$ ) per $0.16 \mathrm{~m}^{2}$. The percentage $(16 \pm 4 \%)$ of those oysters found dead on experimental reefs in May 1994 did not vary significantly with water depth $(18 \pm 6 \%$ at $3 \mathrm{~m}$ vs. $16 \pm 3 \%$ at $4 \mathrm{~m}$ vs. $15 \pm$ $4 \%$ at $6 \mathrm{~m})$, reef height $(15 \pm 4 \%$ on short vs. $17 \pm$ $6 \%$ on tall), position (17 $\pm 4 \%$ at the base vs. $16 \pm$ $5 \%$ on the crest), or any interaction among factors ( $\mathrm{Ta}-$ ble 1). Thus, oyster recruits on experimental reefs dating from August-September 1993 survived well until spring 1994 and revealed no detectable pattern of mortality with water depth.

\section{Oyster mortality in cages prior to hypoxic events}

Mortality of oysters in cages sampled on 5 July 1994 also prior to the anoxic events did not exhibit significant differences between water depths $(32 \pm 21 \%$ at $3 \mathrm{~m}$ vs. $37 \pm 18 \%$ at $6 \mathrm{~m})$, reef heights $(33 \pm 19 \%$ on short vs. $36 \pm 20 \%$ on tall), positions on reef (35 \pm
$20 \%$ on base vs. $34 \pm 21 \%$ on crest), or any interaction among factors (Table 2). Therefore, up to 5 July 1994, we could detect no pattern of oyster mortality with water depth for oysters introduced in August 1993 on experimental reefs in the Neuse River estuary.

\section{Oyster mortality in quadrats after hypoxic events}

Sampling of oysters on reefs on 2 August 1994 after imposition of the two extended oxygen-depletion events demonstrated mass mortality at all water depths below $5 \mathrm{~m}$. This involved all elevations on short reefs and bases of tall reefs at the 6-m station. There was negligible oyster mortality on reefs located in water shallower than $5 \mathrm{~m}$ and on the crests of large reefs located at 6-m water depth (Fig. 4). The three-way statistical interaction among water depth ( $3 \mathrm{~m}$ vs. $6 \mathrm{~m})$, reef height (tall vs. short), and position on reefs (crest vs. base only) was highly significant in all 20 ANOVAs $(P<0.0001$, Table 3$)$. SNK a posteriori contrasts showed bases and crests of short reefs at $6 \mathrm{~m}$ and bases of tall reefs at $6 \mathrm{~m}$ to exhibit significantly greater mortality $(P<0.05$ for all SNK contrasts) than all other treatment combinations. Consequently, the mass mortality of oysters that occurred between 5 July and 2 August 1994 coincided precisely with locations exposed to protracted hypoxia/anoxia.

\section{Status of reef-associated species shortly after hypoxic events}

During oyster sampling on 2 August we observed accumulations of sedentary reef associates (mud crabs, Panopeus herbstii and Eurypanopeus depressus, and two species of blenny fishes, Chasmodes bosquianus and Hypsoblennius hentzi) on tops of reefs at 6-m water depth. The mud crabs and fish on tall reefs were alive ( $n \sim 500-600$ individuals of each species per reef), while all those on short reefs were dead $(n \sim 300-400$ individuals of each species per reef). Assessment of occupancy of burrows of blue crabs on reef bases on 3 and 17 June 1994 prior to the hypoxic/anoxic events revealed that burrows at all depths were $100 \%$ occupied by blue crabs (Fig. 5). Reassessment of burrow occupancy conducted on 3 August immediately following hypoxia/anoxia revealed significantly lower burrow occupancy at $6-\mathrm{m}(0 \%)$ than at $3-\mathrm{m}(75 \%)$ or $4-\mathrm{m}(80 \%)$ water depths, indicative of emigration or death. A $\chi^{2}$ contingency test revealed that the pattern of occupation of burrows with water depth varied significantly $\left(\chi_{0.05,2}^{2}\right.$ $=7.80 ; P=0.02$ ) after hypoxia. By inspection (Fig. $5)$, the change appears in between the last two obser-

FIG. 3. Hydrographic profiles of water temperature from temperature loggers and dissolved oxygen and salinity from conductivity-temperature-depth monitors taken in summer 1994 around experimentally restored oyster reefs in the Neuse River estuary, North Carolina. Vertical temperature stratification is indicated when temperature profiles remain separated over time. Hypoxia/anoxia in bottom waters at the 6-m station occurred during periods of stratification. Salinity is measured on the Practical Salinity Scale. 

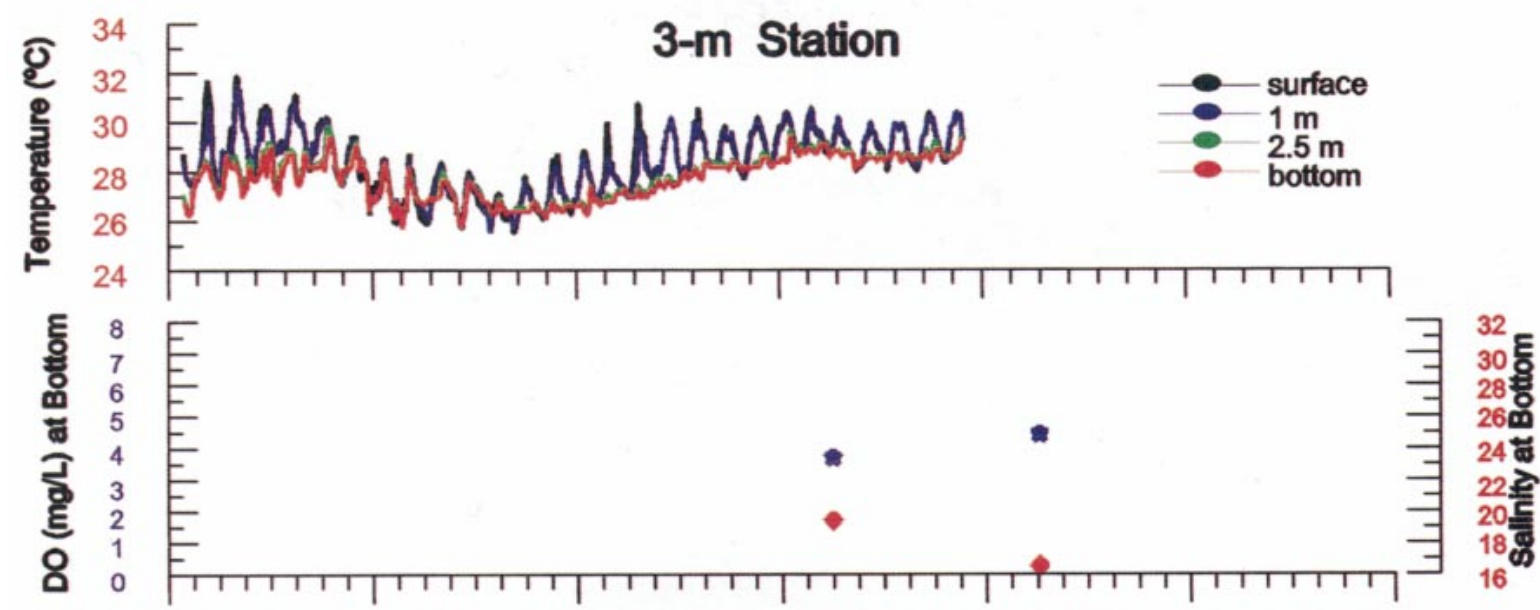

\section{4-m Station}
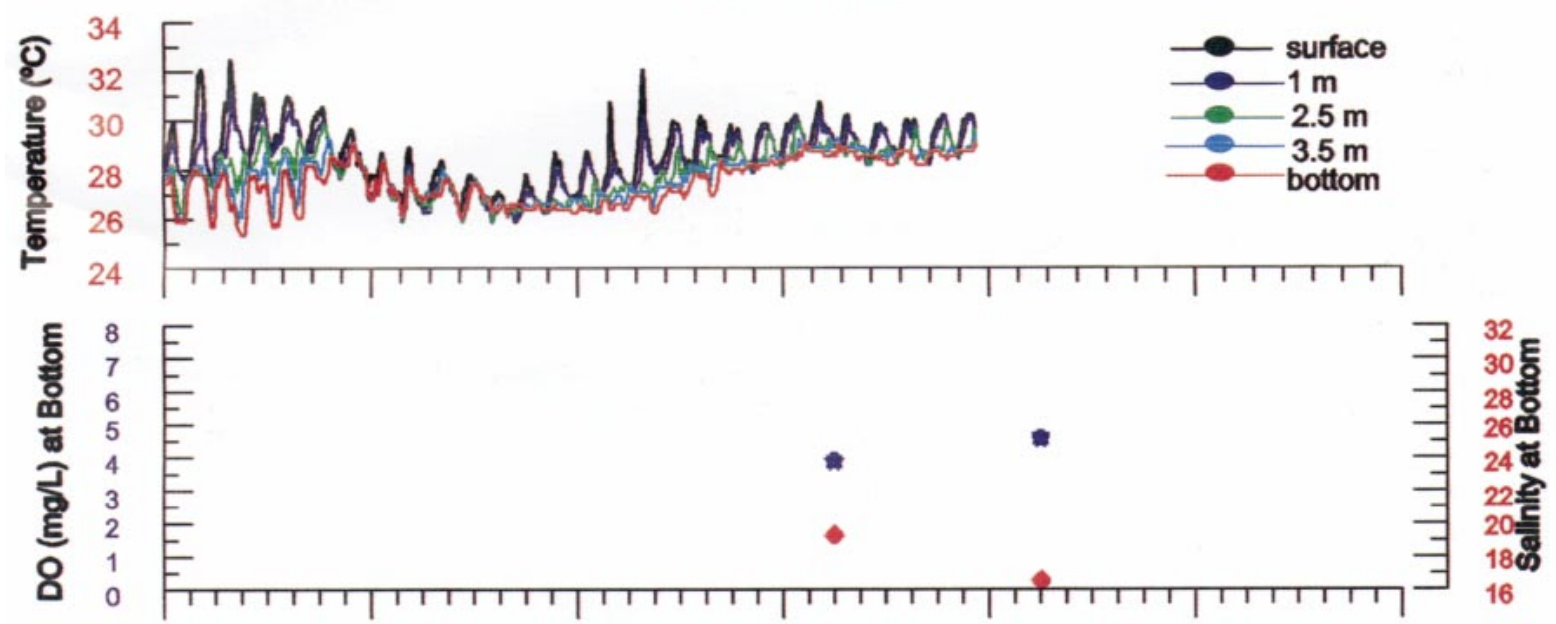

\section{6-m Station}
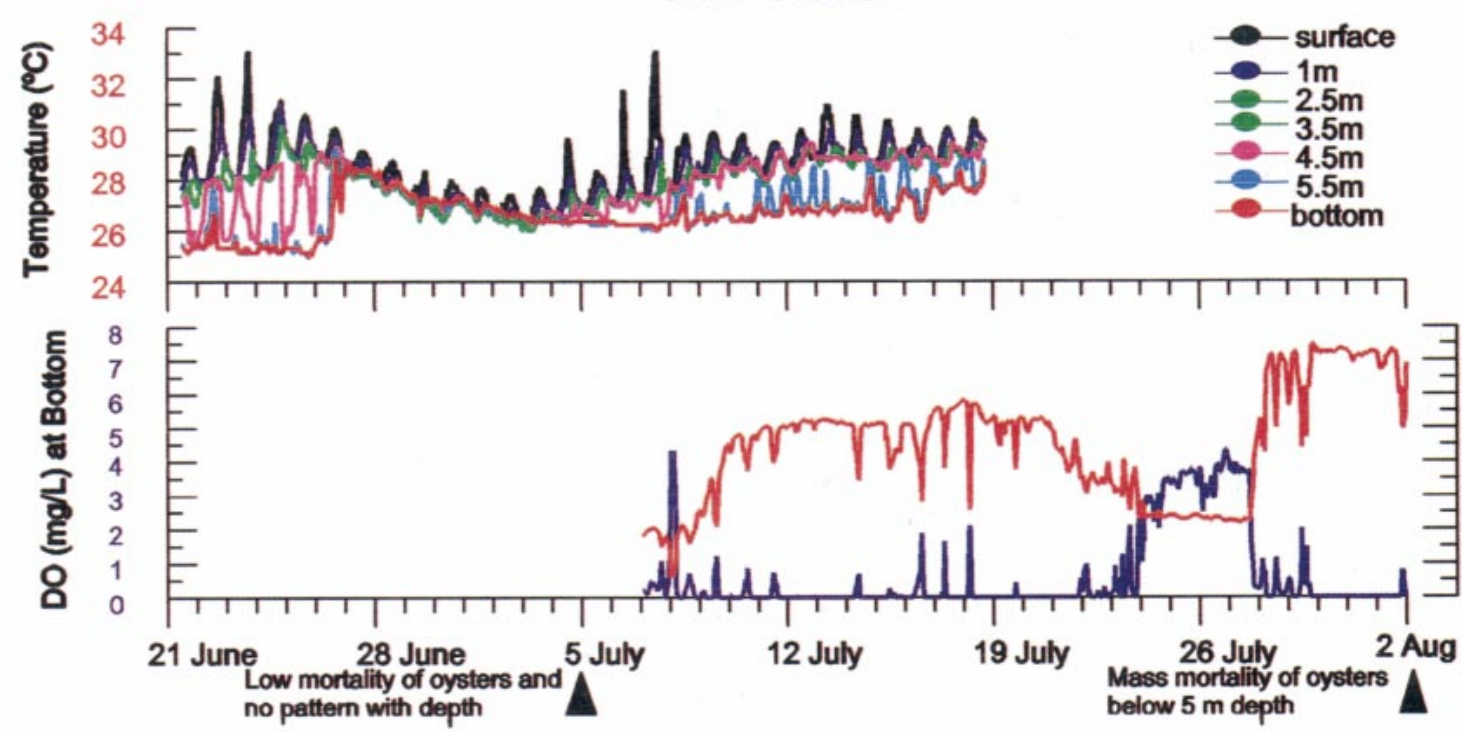
TABLE 1. Results of ANOVAs performed on oyster mortality data collected from recruitment mats on 21 May 1994

\begin{tabular}{lcccc}
\hline \hline $\begin{array}{c}\text { Source of } \\
\text { variation }\end{array}$ & df & MS & $F$ & $P$ \\
\hline Model 1 & & & & \\
$\quad$ Depth, D & 1 & 0.01 & 3.56 & 0.07 \\
Reef height, R & 1 & 0.01 & 3.19 & 0.08 \\
Position, P & 1 & 0.002 & 0.85 & 0.36 \\
D $\times$ R & 1 & 0.005 & 2.18 & 0.15 \\
$\mathrm{D} \times \mathrm{P}$ & 1 & 0.002 & 0.85 & 0.36 \\
$\mathrm{R} \times \mathrm{P}$ & 1 & 0.004 & 1.74 & 0.19 \\
$\mathrm{D} \times \mathrm{R} \times \mathrm{P}$ & 1 & 0.002 & 0.78 & 0.38 \\
Residual & 40 & 0.002 & & \\
Model 2 & & & & \\
Depth, D & 2 & 0.01 & 3.00 & 0.06 \\
Position, P & 1 & 0.001 & 0.74 & 0.40 \\
$\mathrm{D} \times \mathrm{P}$ & 2 & 0.004 & 1.77 & 0.19 \\
Residual & 30 & 0.002 & & \\
\hline
\end{tabular}

Notes: Model 1 provides the results of a three-factor ANOVA testing whether oyster mortality prior to hypoxic/anoxic events varied in response to water depth ( $3 \mathrm{~m}$ vs. $6 \mathrm{~m})$, reef morphology (short vs. tall), position on reef (crest vs. base), and their interactions. Model 2 provides the results of a twofactor ANOVA testing whether oyster mortality on recruitment mats on small reefs prior to hypoxic/anoxic events varied in response to water depth ( $3 \mathrm{~m}$ vs. $4 \mathrm{~m}$ vs. $6 \mathrm{~m})$, position on reef (base vs. crest), and their interactions. Two ANOVA models were used because of an unbalanced experimental design: short $(n=12)$ and tall $(n=12)$ reefs were located at 3- and 6-m water depths, but only short reefs $(n=12)$ were located at $4-\mathrm{m}$ water depth (total of 60 reefs). ANOVAs were conducted on untransformed data because variances were homogeneous (Cochran's tests; Model 1: $C_{\text {crit. }}=0.3362$, $C=0.2500, P>0.05 ;$ Model 2: $C_{\text {crit }}=0.4184, C=0.2500$, $P>0.05) ; C_{\text {crit. }}=$ the critical value of $C$ ).

vation dates, which is when the hypoxic events occurred.

\section{DisCUSSION}

The results of our large-scale field experiments in reef habitat restoration indicate that oysters must be in the surface mixed layer of a stratified estuary to survive extended deep-water hypoxia/anoxia, and that whether oysters survive hypoxic/anoxic events in deep water is contingent on reef height. We found that in deep portions of an estuary, tall experimental oyster reefsthose mimicking natural, undegraded reefs-were more dependable habitat for oysters and other reef organisms than short reefs-those mimicking harvest-degraded reefs-because tall reefs provided refuge above hypoxic/anoxic bottom waters. In addition, we found that both short and tall oyster reefs located in 3-m and 4$\mathrm{m}$ water depths provided better habitat than short reefs located at $6 \mathrm{~m}$ because extended periods of hypoxia/ anoxia did not occur in shallow water. The fact that shallow water acts as a refuge for oyster-reef communities during deep water hypoxia/anoxia was also observed by Seliger et al. (1985) and Breitburg (1992). Our results help explain (1) why oyster harvests from natural reefs in the Neuse River estuary have declined and (2) why we found dead oysters in our survey of reefs in the Neuse to be concentrated in waters deeper
TABLE 2. Results of a three-factor ANOVA testing whether oyster mortality in cages sampled on 5 July 1994 prior to the hypoxic/anoxic events varied in response to water depth (3 m vs. $6 \mathrm{~m}$ ), reef morphology (short vs. tall), position on reef (crest vs. base), and their interactions.

\begin{tabular}{lrllc}
\hline \hline $\begin{array}{c}\text { Source of } \\
\text { variation }\end{array}$ & df & \multicolumn{1}{c}{ MS } & \multicolumn{1}{c}{$F$} & $P$ \\
\hline Depth, D & 1 & 0.08 & 2.05 & 0.15 \\
Reef height, R & 1 & 0.04 & 1.01 & 0.31 \\
Position, P & 1 & 0.005 & 0.13 & 0.72 \\
$\mathrm{D} \times \mathrm{R}$ & 1 & 0.004 & 0.11 & 0.74 \\
$\mathrm{D} \times \mathrm{P}$ & 1 & 0.00008 & 0.002 & 0.96 \\
$\mathrm{R} \times \mathrm{P}$ & 1 & 0.01 & 0.30 & 0.58 \\
$\mathrm{D} \times \mathrm{R} \times \mathrm{P}$ & 1 & 0.002 & 0.04 & 0.83 \\
Residual & 155 & 0.04 & & \\
\hline
\end{tabular}

Notes: Data are given in the text. ANOVAs were performed on untransformed data because variances were homogeneous (Cochran's test: $C_{\text {crit. }}=0.2022, C=0.2020, P>0.05$ ).

2 August 1994
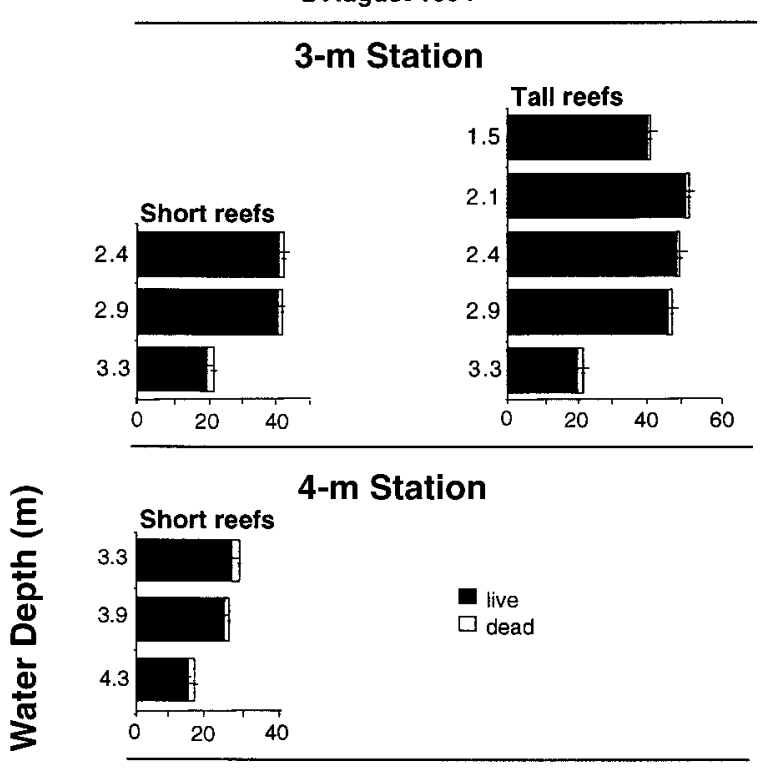

6-m Station
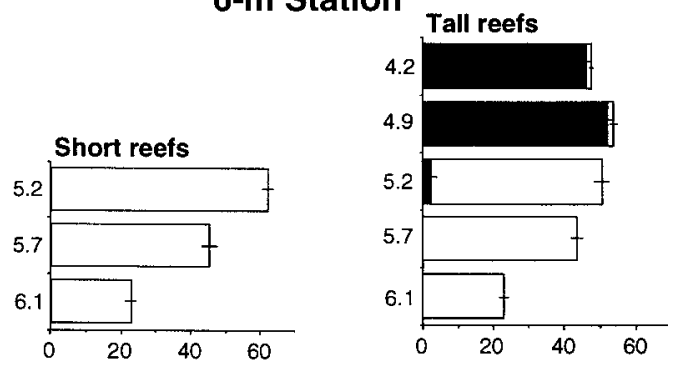

No. Oysters $/ 0.1 \mathrm{~m}^{2}$

FIG. 4. Densities of living and dead oysters on experimentally restored oyster reefs $(n=6)$ after prolonged hypoxia/anoxia, as sampled on 2 August 1994. On short reefs, data were collected from the base of reefs, $40 \mathrm{~cm}$ above the base, and on the crest. On tall reefs, data were collected from the base, at $40 \mathrm{~cm}, 90 \mathrm{~cm}$, and $120 \mathrm{~cm}$ above the base, and on the crest. The deepest water depth shown on each histogram represents the base of reefs and the shallowest depth represents the crest of reefs. Data are means \pm 1 SE. 
TABLE 3. Results of 20 three-factor ANOVAs testing whether oyster mortality in quadrat samples collected on 2 August 1994 immediately following hypoxic/anoxic events varied in response to water depth $(3 \mathrm{~m}$ vs. $6 \mathrm{~m})$, reef height (short vs. tall), position on reef (crest vs. base), and their interactions.

\begin{tabular}{lrrrr}
\hline \hline $\begin{array}{c}\text { Source of } \\
\text { variation }\end{array}$ & df & MS & $F(\times 100)$ & $P$ \\
\hline Depth, D & 1 & $2.88-3.02$ & $101.4-349.2$ & 0.0001 \\
Reef height, R & 1 & $0.33-0.38$ & $125.0-440.0$ & 0.0001 \\
Position, P & 1 & $0.40-0.46$ & $150.0-570.0$ & 0.0001 \\
$\mathrm{D} \times \mathrm{R}$ & 1 & $0.34-0.37$ & $118.0-431.0$ & 0.0001 \\
$\mathrm{D} \times \mathrm{P}$ & 1 & $0.26-0.29$ & $96.0-341.0$ & 0.0001 \\
$\mathrm{R} \times \mathrm{P}$ & 1 & $0.38-0.41$ & $131.0-473.0$ & 0.0001 \\
$\mathrm{D} \times \mathrm{R} \times \mathrm{P}$ & 1 & $0.30-0.35$ & $112.0-399.0$ & 0.0001 \\
Residual & 16 & $0.00008-0.0003$ & & \\
\hline
\end{tabular}

Notes: Data are given in Fig. 4. ANOVAs were performed on 20 randomly assigned combinations of data from the crests and bases of experimental reefs $(n=6) . F$ ratios need be multiplied by 100 to yield true values. All ANOVAs were performed on untransformed data because variances were heterogeneous even after transformation (Cochran's test: $C_{\text {crit. }}=$ 0.4377, $C=0.4447, P<0.05$ for all tests).

than $5 \mathrm{~m}$. Reefs physically altered by cumulative removal of shells during oyster harvest by dredges and hydraulic tongs do not project as high off the estuarine seafloor as natural, undegraded reefs. Thus, more of the component oysters and reef associates located in deep water are subjected to risk of mortality from oxygen depletion of bottom waters. The findings of this study indicate that structural characteristics of oyster reefs (e.g., height) and their location in space (e.g., water depth) interact to affect their function as habitat.

The pattern of oyster mortality on experimental oyster reefs resulting from hypoxia/anoxia supports the general hypothesis that interaction between environmental disturbances can have dramatic effects on biota that differ from the additive effect of each factor (e.g., Erhlich and Roughgarden 1987, Peterson and Black 1988, Rydberg et al. 1990, Myers 1995). Using a largescale manipulative field experiment involving habitat restoration, we found that effects of reef habitat degradation through fishery disturbance, specifically the reduction of reef height, and the effects of bottom water hypoxia combined to dictate the pattern of oyster loss observed in the Neuse River estuary. Besides the decrease in area of oyster-reef habitat (Rothschild et al. 1994), the reduction of reef height through harvesting (see Results: Effect of fishery disturbance . . . , above; DeAlteris 1988) is also likely to have negative influence on resident populations of oysters through reduction of local current flow (Rothschild et al. 1994, H S. Lenihan, unpublished data) and increased sedimentation and burial rates of reefs (H. S. Lenihan, unpublished data). We would expect such physical changes to decrease larval settlement, reduce growth rates, and increase mortality rates of oysters (Turner et al. 1994, Lenihan et al. 1996) but would not expect such changes to cause mass mortality in the reef community under normal hydrographic conditions. Similarly, bottom-wa-

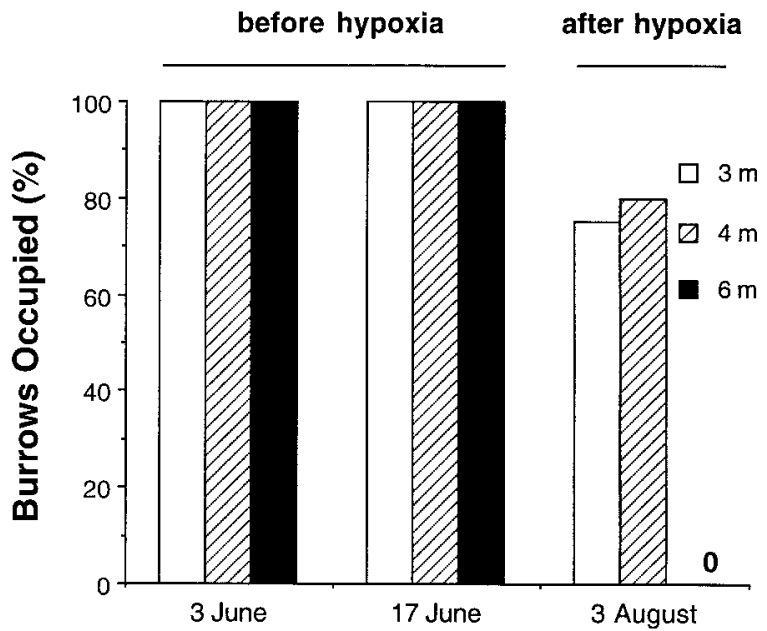

FIG. 5. Percentage of burrows located on the bases of short experimental oyster reefs occupied by blue crabs ( $\mathrm{Cal}$ linectes sapidus) on three dates in the summer of 1994. Bars represent percentage occupancy of reefs at 3-m $(n=5$ burrows), $4-\mathrm{m}$ ( $n=4$ burrows), and $6-\mathrm{m}(n=5$ burrows $)$ water depth before and immediately after hypoxia/anoxia events that occurred near the seafloor at 6-m water depth (see Fig. $3)$.

ter hypoxia/anoxia alone should not destroy entire reef communities if large portions of the reef structure are elevated into the well-mixed surface layers of the water column. Consequently, it is the interaction of habitat degradation through fishery disturbance and bottomwater hypoxia/anoxia that has major negative impacts on oyster reefs located in deeper portions of estuaries.

The findings of our oyster-harvest experiment and comparison of bathymetric surveys (1868 vs. 1993) indicate that dredge harvesting substantially reduces the height of oyster reefs and support our use of short reefs as mimics for harvest-damaged reefs. Our fisherydisturbance experiment shows that less than one full season's worth of harvesting effort reduced the mean height of restored oyster reefs by $30 \%$. This substantial reduction in reef height should not only influence physical-biological coupling over reefs (Breitburg et al. 1995, Leichter and Witman 1997, H. S. Lenihan, unpublished data), and increase susceptibility of reef fauna to bottom-water hypoxia in deep water, but also have important implications for oyster-reef restoration, especially since most of the remaining reefs in North Carolina producing oysters for market are restored reefs (Frankenberg 1995). At an annual removal rate of $30 \%$, restored reefs would be completely destroyed after $<4$ yr of harvesting. This high removal rate may explain why most restored reefs in heavily fished areas in North Carolina must be replaced every 3-4 yr (Frankenberg 1995, M. Marshall, personal communication). The relatively rapid turnover (i.e., restoration following destruction) effectively creates a "put-and-take" fishery in which oyster-reef habitat is restored solely for 
the fishery and not preserved for its other ecosystem functions.

We expect that dredging should cause greater reductions in the height of restored oyster reefs than natural oyster reefs because the shell matrix of natural reefs is more effectively cemented together by the progressive accumulation of settling benthic organisms. In contrast, restored reefs are initially piles of loose shell that appear to attain only a small degree of cohesion over their short life-spans. Nevertheless, it is likely that the height of natural reefs is also reduced by dredging over periods of decades because a large portion $(\sim 50 \%)$ of material extracted from natural reefs by dredges is shell matrix (Hargis and Haven 1988, H. S. Lenihan, personal observation). Our contention that the height of natural reefs in the Neuse River estuary has been reduced by mechanical harvesting over the last century is further supported by the results of our bathymetric survey and surveys conducted in Chesapeake Bay (DeAlteris 1988, Rothschild et al. 1994). Although Rothschild et al. (1994) did not quantitatively evaluate reef height in Chesapeake Bay, they describe a harvestrelated reduction in reef height qualitatively.

We suggest that the frequency and spatial extent of hypoxia/anoxia and consequent oyster mortality is likely to have increased over the last several decades in the Neuse River estuary due to increased anthropogenic nutrient loading. We base this suggestion on a recent study by Paerl et al. (1995) indicating that increased anthropogenic inputs of nitrogen into the Neuse River from sewage disposal, agricultural runoff, ground-water seepage, and atmospheric deposition have led to spatial and temporal expansion of eutrophication. Eutrophication is defined as an increase in the rate of supply of organic material to an ecosystem (Nixon $1995)$, and the primary cause of eutrophication in marine and estuarine ecosystems is anthropogenic loading of nitrogen and phosphorous (National Research Council 1993). The data required to test the hypothesis that spatial and temporal expansion of hypoxia and anoxia has increased with eutrophication in the Neuse River estuary are not available. However, based on first principles, we argue that increased eutrophication necessarily leads to increased hypoxia and anoxia in the Neuse, as appears to be the case in many estuaries worldwide (Cooper and Brush 1991, Smith et al. 1992, Dyer and Orth 1994).

Loss of oysters and oyster reef habitat may have important negative consequences for the sustainability, economic value, and biodiversity of estuarine ecosystems. Through their active filtration, oysters remove vast quantities of suspended particles, including phytoplankton, from estuarine waters (Dame et al. 1984, Newell 1988). The loss of oyster populations removes one potential means of controlling nuisance phytoplankton blooms and other deleterious influences of nutrient enrichment and coastal eutrophication (Officer et al. 1982, Newell 1988). It follows that the restoration of oysters can be viewed as a form of biomanipulation (Carpenter et al. 1995) to counteract eutrophication. Oyster reefs are habitat for recreationally and commercially important fishes and invertebrates, such as drums, rockfish, speckled seatrout, shrimps, and blue crabs (Arve 1960, Bahr and Lanier 1981, H. S. Lenihan, unpublished data). Oysters may now be more economically valuable for the habitat they provide for other valued species than they are for the oyster fishery. As creators of biogenic reef structure, oyster reefs also contribute to maintenance of biodiversity in estuaries (e.g., Wells 1961), and, therefore, function in a manner similar to tropical coral reefs (e.g., Norse 1993). Unfortunately, oyster reefs are rarely appreciated as analogs to coral reefs. In the United States, oysters are managed by state fisheries agencies, which have not consistently regulated harvests of fish stocks in a sustainable manner (Ludwig et al. 1993), and do not preserve and restore oysters and oyster reefs for their many ecosystem services.

A commitment to ecosystem management (Christensen et al. 1996) in the coastal zone may require transfer of responsibility for oysters from fisheries managers to coastal habitat managers, who have traditionally protected and restored habitat in ways more consistent with sustaining ecosystem services (Thayer 1992). Our demonstration of interaction between factors now typically managed by separate agencies (oyster reef habitat and water quality) shows that biological consequences of management decisions by one agency are contingent upon those made by another. Such factor interactions require the integrated synthesis of ecological complexity that defines ecosystem management. This study represents a clear demonstration of Myers' (1995) contention that synergistic interactions between environmental factors must be acknowledged and identified to ensure effective management of natural resources.

\section{ACKNOWLEDGMENTS}

We thank M. Marshall and J. French for building and preserving our experimental reefs, and G. Bath, J. Byers, W. Falls, J. French, J. Grabowski, A. Maxson, F. Micheli, H. Summerson, and P. Wyrick for help in the field. Comments of M. Hay, R. Luettich, C. Martens, B. Menge, J. McNinch, F. Micheli, H. Paerl, B. Peierls, J. Pinkney, J. Wells, and two anonymous reviewers substantially improved the manuscript. D. Colby, L. Crowder, and F. Micheli provided expert advice on statistical analyses. Funding was provided by the North Carolina General Assembly through the Cooperative Institute of Fishery Oceanography, the PEW Charitable Trust, the National Oceanic and Atmospheric Administration-Chesapeake Bay Oyster Disease Program, and the National Research Council.

\section{Literature Cited}

Arve, R. 1960. Preliminary report on attracting fish by oyster-shell plantings in Chincoteague Bay, MD. Chesapeake Science 1:58-65.

Bahr, L. M., and W. P. Lanier. 1981. The ecology of intertidal oyster reefs of the south Atlantic coast: a community profile. FWS/OBS/81.15. U.S. Fish and Wildlife Service, Washington, D.C., USA.

Bell, S. S., E. D. McCoy, and H. R. Mushinsky, editors. 1991. 
Habitat structure: the physical arrangement of objects in space. Chapman \& Hall, London, UK.

Belsky, A. J., R. G. Ammundson, J. M. Duxbury, S. J. Riha, A. R. Ali, and S. M. Mwonga. 1989. The effects of trees on their physical, chemical, and biological environments in semi-arid savannah in Kenya. Journal of Applied Ecology 26:1005-1024.

Breitburg, D. L. 1992. Episodic hypoxia in Chesapeake Bay: interacting effects of recruitment, behavior, and physical disturbance. Ecological Monographs 62:525-546.

Breitburg, D. L., M. A. Palmer, and T. Loher. 1995. Larval distributions and the spatial patterns of settlement of an oyster reef fish: response to flow and structure. Marine Ecology Progress Series 125:45-60.

Carpenter, S. R., S. W. Chisholm, C. J. Krebs, D. W. Schindler, and R. F. Wright. 1995. Ecosystem experiments. Science 269:324-327.

Christensen, N. L., A. M. Bartuska, J. H. Brown, S. R. Carpenter, C. D'Antonio, R. Francis, J. F. Franklin, J. A. Mc Mahon, R. F. Noss, D. J. Parsons, C. H. Peterson, M. G. Turner, and R. G. Woodmansee. 1996. Report of the Ecological Society of America Committee on the Scientific Basis for Ecosystem Management. Ecological Applications 6:665-691.

Chu, F.-L. E., A. K. Volety, and G. Constantin. 1994. Synergistic effects of temperature and salinity on the response of oyster (Crassostrea virginica) to the pathogen Perkinsus marinus. Journal of Shellfish Research 13:293.

Cooper, S. R., and G. S. Brush. 1991. A 2500 year history of anoxia and eutrophication in the Chesapeake Bay. Science 254:992-1001.

Dame, R. F. 1979. The abundance, diversity, and biomass of macrobenthos on North Inlet, South Carolina, intertidal oyster reefs. Proceedings of the National Shellfish Association 69:6-10.

Dame, R. F., R. G. Zingmark, and E. Haskin. 1984. Oyster reefs as processors of estuarine material. Journal of Experimental Marine Biology and Ecology 83:239-247.

Dayton, P. K., S. F. Thrush, M. T. Agardy, and R. J. Hoffman. 1995. Environmental effects of marine fishing. Aquatic Conservation: Marine and Freshwater Ecosystems 5:205232.

DeAlteris, J. T. 1988. The geomorphologic development of Wreck Shoal, a subtidal oyster reef of the James River, Virginia. Estuaries 11:240-249.

Dyer, K. R., and R. J. Orth, editors. 1994. Changes in fluxes in estuaries: implications from science to management. Olsen and Olsen, Fredensburg, Denmark.

Ehrlich, P. R., and J. Roughgarden. 1987. The science of ecology. MacMillan, New York, New York, USA.

Estes, J. A., and D. O. Duggins. 1995. Sea otters and kelp forests in Alaska: generality and variation in a community ecological paradigm. Ecological Monographs 65:75-100.

Fisher, W. S. 1996. Preface. Journal of Shellfish Research 15: 1 .

Ford, S. E. 1996. Range extension by the oyster parasite Perkinsus marinus into the northeastern United States: Response to climate change? Journal of Shellfish Research 15:45-56.

Ford, S. E., and M. R. Tripp. 1996. Diseases and defense mechanisms. Pages 581-660 in V. S. Kennedy, R. I. E. Newell, and A. F. Ebele, editors. The eastern oyster, Cras sostrea virginica. Maryland Sea Grant, College Park, Maryland, USA.

Frankenberg, D. 1995. Report of North Carolina Blue Ribbon Advisory Council on Oysters. North Carolina Department of Environment, Health, and Natural Resources, Raleigh, North Carolina, USA.

Gause, G. F. 1934. The struggle for existence. Williams \& Williams, Baltimore, Maryland, USA.
Genin, A., P. K. Dayton, P. F. Lonsdale, and F. N. Spiess. 1986. Corals on seamounts: evidence of current accelerations over deep-sea topography. Nature 332:59-61.

Grant, J., C. T. Enright, and A. Griswold. 1990. Resuspension and growth of Ostrea edulis: a field experiment. Marine Biology 104:51-59.

Gross, F., and J. C. Smyth. 1946. The decline of oyster populations. Nature 157:540-542.

Hargis, W. J., Jr., and D. S. Haven. 1988. The imperiled oyster industry of Virginia: a critical analysis with recommendations for restoration. Special report Number 290 in applied marine science and ocean engineering, Virginia Sea Grant Marine Advisory Services. Virginia Institute of Marine Science, Gloucester Point, Virginia, USA.

Hatcher, B. G., R. E. Johannes, and A. I. Robertson. 1989. Review of the research relevant to the conservation of shallow tropical marine ecosystems. Oceanography and Marine Biology Annual Review 27:337-414.

Heck, K. L., and R. J. Orth. 1980. Seagrass habitats: the roles of habitat complexity, competition, and predation in structure-assisted fish and motile macroinvertebrate assemblages. Pages 449-464 in V. S. Kennedy, editor. Estuarine perspectives. Academic Press, New York, New York, USA.

Hixon, M. A., and J. P. Beets. 1993. Predation, prey refuges, and the structure of coral-reef fish assemblages. Ecological Monographs 63:77-101.

Hixon, M. A., and B. A. Menge. 1991. Species diversity: prey refuges modify the interactive effects of predation and competition. Theoretical Population Biology 39:178-200.

Holt, R. D. 1984. Spatial heterogeneity, indirect interactions, and the coexistence of prey species. American Naturalist 124:377-406.

Ingersoll, I. 1881. The oyster industry. Pages 156-180 in Tenth census of the U.S.A. Department of the Interior, Washington, D.C., USA.

Irlandi, E. A. 1996. The effects of seagrass patch size and energy regime on growth of a suspension-feeding bivalve. Journal of Marine Research 54:161-185.

Irlandi, E. A., and C. H. Peterson. 1988. Modification of animal habitat by large plants: mechanisms by which seagrasses influence clam growth. Oecologia 87:307-318.

Johannes, R. E. 1976. Words of the lagoon. University of California Press, Berkeley, California, USA.

Jones, C. G., J. H. Lawton, and M. Shachak. 1994. Organisms as ecosystem engineers. Oikos 69:373-386.

Jordan, S., C. Stenger, M. Olson, R. Batiuk, and K. Mountford. 1992. Chesapeake Bay dissolved oxygen goal for restoration of living resources. United States Environmental Protection Agency, Chesapeake Bay Program, Annapolis, Maryland, USA.

Klopfer, P. H., and R. MacArthur. 1960. Niche size and faunal diversity. American Naturalist 94:293-300.

Kneib, R. T. 1984. Pattern of invertebrate distribution and abundance in the intertidal salt-marsh: causes and questions. Estuaries 7:392-412.

Leather, S. R. 1986. Insect species richness of the British Rosaceae: importance of host range, plant architecture, age of establishment, taxonomic isolation, and species-area relationship. Journal of Animal Ecology 55:841-860.

Leichter, J. J., and J. D. Witman. 1997. Water flow over subtidal rock walls: relation to distributions and growth rates of sessile suspension feeders in the Gulf of Maine. Journal of Experimental Marine Biology and Ecology 209: 293-307.

Lenihan, H. S., C. H. Peterson, and J. M. Allen. 1996. Does flow speed also have a direct effect on growth of active suspension feeders: an experimental test on oysters, Crassostrea virginica (Gmelin). Limnology and Oceanography 41:1359-1366.

Llanso, R. J. 1993. Effects of hypoxia on estuarine benthos: 
the lower Rappahannock River (Chesapeake Bay), a case study. Estuarine, Coastal and Shelf Science 35:491-515.

Ludwig, D., R. Hilborn, and C. Walters. 1993. Uncertainty, resource exploitation, and conservation: lessons from history. Science 260:17,36.

MacArthur, R. H., and R. Levins. 1964. Competition, habitat selection, and character displacement in a patchy environment. Proceedings of the National Academy of Sciences (USA) 51:1207-1210.

MacArthur, R. H., and J. W. MacArthur. 1961. On bird species diversity. Ecology 42:594-598.

MacKenzie, C. L. 1996. Management of natural populations Pages 707-721 in V. S. Kennedy, R. I. E. Newell, and A. F. Ebele, editors. The eastern oyster, Crassostrea virginica. Maryland Sea Grant, College Park, Maryland, USA.

Marshall, N. 1954. Changes in the physiography of oyster bars in the James River, Virginia. Virginia Journal of Science 5:173-181.

Murdoch, W. W., F. C. Evans, and C. H. Peterson. 1972. Diversity and pattern in plants and insects. Ecology 53: 819-829.

Myers, N. 1995. Environmental unknowns. Science 269: 358-360.

National Research Council. 1993. Managing wastewater in coastal urban areas. National Academy Press, Washington, D.C., USA.

Newell, R. I. E. 1988. Ecological changes in Chesapeake Bay: are they the result of overharvesting the American oyster? Pages 536-546 in M. P. Lynch and E. C. Krome, editors. Understanding the estuary: advances in Chesapeake Bay research. Publication 129. Chesapeake Bay Research Consortium, Baltimore, Maryland, USA.

Nixon, S. W. 1995. Coastal marine eutrophication: a definition, social causes, and future concerns. Ophelia 41:199219.

Norse, E. A., editor. 1993. Global marine biological diversity: a strategy for building conservation into decision making. Island Press, Washington, D.C., USA.

Northridge, S. 1991. The environmental impacts of fisheries in the European Community waters. A report to the European Commission's Directorate General Environment, Nuclear Safety and Civil Protection, Marine Resources Assessment Group Ltd., Brussels, Belgium.

Officer, C. B., R. B. Biggs, J. L. Taft, L. E. Cronin, M. A Tyler, and W. R. Boynton. 1984. Chesapeake Bay anoxia: origin, development, and significance. Science 223:22-25.

Officer, C. B., T. J. Smayda, and R. Mann. 1982. Benthic filter feeding: a natural eutrophication control. Marine Ecology Progress Series 9:203-210.

Paerl, H. W. 1985. Enhancement of marine primary production by nitrogen-enriched acid rain. Nature 316:747-749.

Paerl, H. W., M. M. Mallin, C. A. Donahue, M. Go, and B. L. Peierls. 1995. Nitrogen loading sources and eutrophication of the Neuse River, North Carolina: direct and indirect roles of atmospheric deposition. Publication 291. Water Resources Research Institute, University of North Carolina, Chapel Hill, North Carolina, USA.

Peterson, C. H., and R. Black. 1988. Density-dependent mortality caused by physical stress interacting with biotic history. American Naturalist 131:257-270.

Peterson, C. H., H. C. Summerson, and S. R. Fegley. 1987. Ecological consequences of mechanical harvesting of clams. Fishery Bulletin 85:281-298.

Purchon, R. D. 1977. The biology of the mollusca. Pergamon, Oxford, UK.

Reise, K. 1982. Long-term changes in the macrobenthic invertebrate fauna of the Wadden Sea: are polychaetes about to take over? Netherlands Journal of Sea Research 16:2936.
Rothschild, B. J., J. S. Ault, P. Goulletquer, and M. Héral. 1994. Decline of the Chesapeake Bay oyster population: a century of habitat destruction and overfishing. Marine Ecology Progress Series 111:29-39.

Russ, G. R., and A. C. Acala. 1989. Effects of intense fishing pressure on an assemblage of coral reef fishes. Marine Ecology Progress Series 56:13-27.

Rydberg, L., L. Edler, S. Floderus and W. Graneli. 1990. Interaction between supply of nutrients, primary production, sedimentation and oxygen consumption in SE Kattegat. Ambio 19:134-141.

Safriel, U. N. 1975. The role of vermetid gastropods in the formation of Mediterranean and Atlantic reefs. Oecologia 20:85-101.

Seliger, H. H., J. A. Boggs, and W. H. Biggley. 1985. Catastrophic anoxia in the Chesapeake Bay in 1984. Science 228:70-73.

Simenstad, C. A., J. A. Estes, and K. W. Kenyon. 1978. Aleuts, sea otters, and other alternate stable-state communities. Science 200:403-411.

Smith, D. E., M. G. Lefler, and G. MacKiernan. 1992. Oxygen dynamics in Chesapeake Bay: a synthesis of research. Maryland SeaGrant College, College Park, Maryland, USA.

Stanley, D. W., and S. W. Nixon. 1992. Stratification and bottom-water hypoxia in the Pamlico River estuary. Estuaries 15:270-281.

Tegner, M. J., and P. K. Dayton. 1987. El Niño effects on Southern California kelp forest communities. Advances in Ecological Research 17:243-279.

Tenore, K. R. 1972. Macrobenthos of the Pamlico River estuary, North Carolina. Ecological Monographs 42:51-69.

Thain, J. E., and M. J. Waldock. 1986. The impact of tributyltin (TBT) antifouling paints on molluscan fisheries. Water Science Technology 18:193-202.

Thayer, G. W., editor. 1992. Restoring the nation's marine environment. Maryland Sea Grant, College Park, Maryland, USA.

Turner, E. J., R. K. Zimmer-Faust, M. A. Palmer, and M. Lukenbach. 1994. Settlement of oyster (Crassostrea virginica) larvae: effects of water flow and water-soluble chemical cues. Limnology and Oceanography 39:15791593.

Turner, R. E., W. W. Schroeder, and W. J. Wiseman Jr. 1987. The role of stratification in the deoxygenation of Mobile Bay and adjacent shelf-bottom waters. Estuaries 10:13-19.

USCGS [United States Coast and Geodetic Survey]. 1886. Hydrographic Survey, H-974 and H-963. United States Department of Commerce, National Oceanic and Atmospheric Administration, National Ocean Service, Silver Spring, Maryland, USA.

Wells, H. W. 1961. The fauna of oyster reefs with special reference to the salinity factor. Ecological Monographs 31: 239-266.

Wilson, J-B., and A. D. Q. Agnew. 1992. Positive-feedback switches in plant communities. Advances in Ecological Research 23:263-336.

Wilson, W. H., Jr. 1979. Community structure and species diversity of the sediment reefs constructed by Petaloproctus socialis (Polychaeta: Maldanidae). Journal of Marine Research 37:623-641.

Winslow, F. 1889. Report on the sounds and estuaries of North Carolina with reference to oyster culture. United States Coast and Geodetic Survey, Bulletin 10:52-137.

Zimmerman, R., T. J. Minello, T. Baumer, and M. Castiglione. 1989. Oyster reef as habitat for estuarine macrofauna. Technical Memorandum NMFS-SEFC-249. National Oceanic and Atmospheric Administration, Washington, D.C., USA. 